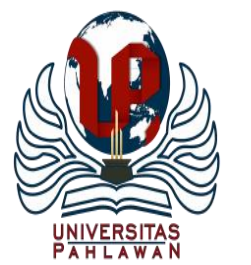

Edukatif : Jurnal Ilmu Pendidikan Volume 3 Nomor 2 Tahun 2021 Halm 304 - 313 EDUKATIF: JURNAL ILMU PENDIDIKAN

Research \& Learning in Education

https://edukatif.org/index.php/edukatif/index

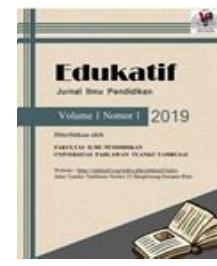

\title{
Meta-Analisis Pengaruh Penggunaan Media Audio Visual Terhadap Hasil Belajar IPS Siswa di Sekolah Dasar
}

\author{
Rosalia Isnaeni ${ }^{1 凶}$, Elvira Hoesein Radia ${ }^{2}$ \\ Pendidikan Guru Sekolah Dasar, Universitas Kristen Satya Wacana, Indonesia ${ }^{1,2}$ \\ E-mail : 292017094@ student.uksw.edu ${ }^{1}$ elvira.hoesein@ uksw.edu $^{2}$
}

\begin{abstract}
Abstrak
Penelitian ini bertujuan untuk menganalisis kembali pengaruh media audio visual terhadap hasil belajar IPS siswa kelas 5 Sekolah Dasar. Penelitian dengan judul Penggunaan Media Audio Visual terhadap hasil belajar IPS sudah banyak dilakukan sebelumnya. Namun, belum terdapat kajian lebih lanjut mengenai hasil penelitian yang merangkum dan menganalisis pengaruh penggunaan media audio visual terhadap hasil belajar IPS. Media audio visual adalah seperangkat alat yang memadukan unsur suara dan gambar sehingga dapat menanamkan konsep konkret yang dapat dilihat, didengar dan diamati. Langkah pertama, peneliti merumuskan masalah kemudian dilanjutkan dengan mengumpulkan data penelitian yang sudah ada melalui penelusuran google scholar. Dari hasil penelusuran, didapatkan 9 artikel dari jurnal, 1 prosiding dan 2 skripsi dari repository yang relevan. Hasil penelitian dari para peneliti dianalisis dengan metode pembanding kuantitatif. Data yang diperoleh merupakan hasil penelitian yang sudah dilakukan sebelumnya yang kemudian dianalisis menggunakan teknik meta-analisis besar pengaruh atau effect size. Dari hasil analisis 12 penelitian, perhitungan effect size sebesar 3,10 yang menunjukkan nilai effect size yang tinggi. Berdasarkan hasil analisis ternyata media audio visual berpengaruh terhadap peningkatan hasil belajar IPS siswa kelas 5 sekolah dasar. Pengaruh penggunaan media audio visual yaitu dapat meningkatkan hasil belajar IPS siswa kelas 5 sekolah dasar mulai dari yang terendah 12,36 $\%$ sampai yang tertinggi 81,81 \% dengan rata-rata peningkatan sebesar 37,96\%.
\end{abstract}

Kata Kunci: Media Audio Visual, Hasil Belajar IPS, Sekolah Dasar.

\begin{abstract}
The purpose of this study to analyze the effect of audio visual media on the result of learning social science of 5th grade students elementary school. Research with the title of audio visual media on the result of learning social science learning outcomes has been done before. However, there is no further study regarding the results of research which is summarized and analyzes the effect of the application of audio visual media on the result of learning social science learning outcomes. Audio visual media is a set of integrated tools which combines the sound, image, and than it can instill concrete the concepts that can be seen heard. First, researcher formulated the problem and then proceeded to collect researchs data that was already through google scholar. From the search, 10 articles from jurnals, 1 prociding and 1 minithesis from relevant repository. The research results from the reseacher were analyzed by quantitative comparison methods. The data obtained is the result of research that has been done before which is then analyzed using a meta-analysis technique of influence or effect size. From the results of the analyzed of 12 studies, the effect size calculation is 3,10 which indicates a high effect size value. Based on the results of the analysis, that audio visual media has an effect on improving the learning of 5th grade students. The effect of using audiovisual media is that can improve social studies outcomes learning of 5th grade students of started from the lowest 12,36 \% until the highest $81,81 \%$ with an avarage increase of $31,96 \%$.
\end{abstract}

Keywords: Audio Visual Media, Social Studies Outcomes, Elementary School.

Copyright (c) 2021 Rosalia Isnaeni, Elvira Hoesein Radia

$\triangle$ Corresponding author

Email :292017094@student.uksw.edu

DOI $\quad$ : https://doi.org/10.31004/edukatif.v3i2.281

ISSN 2656-8063 (Media Cetak)

ISSN 2656-8071 (Media Online)

Edukatif : Jurnal Ilmu Pendidikan Vol 3 No 2 Tahun 2021 p-ISSN 2656-8063 e-ISSN 2656-8071 
305 Meta-Analisis Pengaruh Penggunaan Media Audio Visual Terhadap Hasil Belajar IPS Siswa di Sekolah Dasar - Rosalia Isnaeni, Elvira Hoesein Radia

DOI : https://doi.org/10.31004/edukatif.v3i2.281

\section{PENDAHULUAN}

Kehidupan tak pernah lepas kaitannya dengan pendidikan. Dalam Undang-Undang Nomor 20 Tahun 2003 tentang Sistem Pendidikan Nasional, tertulis bahwa pendidikan merupakan usaha sadar dan terencana untuk mewujudkan suasana belajar dan proses pembelajaran agar peserta didik secara aktif mengembangkan potensi dirinya untuk memiliki kekuatan spiritual keagamaan, pengendalian diri, kepribadian, kecerdasan, akhlak mulia, serta keterampilan yang diperlukan dirinya, masyarakat, mengembangkan segala potensi yang dimiliki peserta didik melalui proses pembelajaran. Sejatinya pendidikan merupakan proses pengubahan sikap dan tata laku seseorang atau kelompok dalam usaha mendewasakan manusia melalui upaya pengajaran dan latihan (Anhusadar, 2016). Dengan adanya pendidikan, membuat seseorang memiliki sikap, pengetahuan dan keterampilan yang lebih baik untuk hidupnya di masa depan. Mutu pendidikan yang baik akan berhasil mencetak generasi bangsa yang baik pula. Menurut Sista (2017) salah satu indikator peningkatan mutu dalam pendidikan ialah dengan penerapan dan pengembangan kurikulum yang sesuai dengan kondisi dan kebutuhan masyarakat, mengikuti kemajuan ilmu pengetahuan dan teknologi, pembelajaran yang mendukung aspek spiritual, intelektual, sosial, emosional, kinestetik dan mengembangkan potensi peserta didik. Di Indonesia saat ini, telah menerapkan Kurikulum 2013 sebagai salah satu usaha untuk meningkatkan mutu pendidikan yang tidak hanya menilai aspek kognitif, namun juga menilai afektif dan psikomotor peserta didik. Beberapa prinsip pembelajaran dalam Kurikulum 2013 ialah pembelajaran yang student center, interaktif, inspiratif, menyenangkan, menantang, memotivasi peserta didik untuk aktif serta memberikan kesempatan untuk membangun dan mengembangkan kreativitas peserta didik, pemanfaatan teknologi informasi dan komunikasi Shafa, (2014). Akan tetapi, saat ini penerapan prinsip Kurikulum 2013 belum berjalan dengan utuh. Banyak guru yang yang seharusnya melaksanakan pembelajaran student center justru masih terbalik menjadi teacher center karena guru lebih banyak menggunakan metode ceramah.

Berdasarkan hasil penelitian Sekarini, Abadi, \& Ganing (2014) pada tahun 2014 di SD I Gusti Ngurah Rai penggunaan metode ceramah dan pemberian tugas di sekolah tersebut cenderung menciptakan kebosanan dan kurang semangat dalam lingkungan belajar. Hal ini juga dikarenakan kurangnya penggunaan media yang variatif dalam pembelajaran. Sama halnya dengan kasus yang ditemui oleh Hutauruk \& Simbolon, (2018) di SD N 14 Simbolon Purba pada tahun 2014, bahwa sekolah masih menggunakan metode ceramah sehingga peserta didik hanya menjadi penonton saja dan melaksanakan aktivitas jika ada perintah ataupun masukan dari guru serta mengerjakan soal-soal latihan di buku. Pembelajaran yang monoton menjadi salah satu pemicu kebosanan dan kurang aktifnya siswa. Menurut Hergenhahn dan Olson Yuzarion, (2017), ada 2 faktor yang mempengaruhi keberhasilan belajar yaitu faktor internal dan faktor eksternal. Jadi, kondisi pembelajaran yang mononton merupakan faktor eksternal yang dapat mempengaruhi hasil belajar peserta didik. Peserta didik cenderung kurang memperhatikan saat bosan mengikuti pembelajaran dan berimbas pada hasil belajarnya yang rendah terutama di sekolah dasar. Padahal hasil belajar merupakan salah satu indikasi penting yang menunjukkan kualitas mutu pendidikan. Oleh karena itu, guru sebagai seorang pendidik dituntut harus memiliki pengetahuan dan keterampilan yang kreatif dan inovatif dalam melaksanakan pembelajaran yang variatif, terutama bagi peserta didik yang duduk di sekolah dasar.

Peserta didik usia sekolah dasar berada pada fase perkembangan operasional konkret sesuai dengan teori yang dicetuskan oleh Piaget (Ibda, 2015). Dengan demikian, guru memerlukan media pembelajaran yang menampilkan sesuatu yang nyata dan menarik sehingga materi yang disampaikan mudah dipahami oleh peserta didik. Seperti halnya yang disebutkan menurut Falahudin (2014), bahwa media pembelajaran dapat membuat proses pembelajaran lebih jelas dan menarik sehingga pembelajaran tidak membosankan dan monoton. Saat peserta didik tertarik dengan pembelajaran, secara otomatis ia akan mengikuti dan berusaha memahami pembelajaran dengan baik. Lebih lanjut menurut Falahudin (2014), menyebutkan bahwa media 
pembelajaran dapat meningkatkan kualitas hasil belajar karena dapat membantu peserta didik menyerap materi pembelajaran lebih mendalam dan utuh.

Ada banyak media pembelajaran yang bisa digunakan oleh guru untuk membantu menyampaikan materi dalam pembelajaran. Salah satu media pembelajaran yang dapat digunakan adalah media audio visual. Media audio visual merupakan media yang memadukan unsur suara dan gambar yang bisa dibuat maupun dicari melalui teknologi. Perkembangan zaman yang semakin canggih juga memunculkan banyak aplikasi yang dapat dimanfaatkan guru untuk membuat media pembelajaran audio visual dengan mudah atau guru juga dapat memanfaatkan internet untuk mencari media pembelajaran audio visual di youtube. Menurut Sanaky Sekarini, Abadi, \& Ganing (2014), menyebutkan bahwa media audio visual merupakan seperangkat alat yang dapat memproyeksikan gambar bergerak dan bersuara. Di mana peserta didik dapat mengamati gambar dan warna yang konkrit serta perpaduan suara. Hal ini sejalan dengan pendapat Rinanto (1982) yang mengatakan bahwa media audio visual dapat menanamkan konsep dasar yang besar, konkret dan realistik dapat dilihat, didengar dan diamati serta direfleksikan oleh peserta didik. Media pembelajaran audio visual jika digunakan dalam pembelajaran IPS di kelas 5, maka ini merupakan langkah yang tepat untuk mengatasi permasalahan rendahnya hasil belajar IPS. Mengingat pembelajaran IPS terkait dengan peristiwa masa lampau dan juga peristiwa kenampakan alam yang belum tentu dapat disaksikan oleh siswa secara langsung, media audio visual dapat mengatasi keterbatasan itu. Berdasarkan uraian tersebut, maka fokus penelitian ini yaitu menganalisis kembali apakah penggunaan media audio visual dari berbagai hasil penelitian yang dipublikasi berpengaruh terhadap hasil belajar muatan IPS siswa kelas 5 sekolah dasar? Dan apakah dengan penggunaan model TPS (Thinks Pair Share) berbantuan media audio visual dari berbagai hasil penelitian yang dipublikasi berpengaruh terhadap hasil belajar muatan IPS siswa kelas 5 sekolah dasar?

\section{METODE PENELITIAN}

Jenis penelitian yang digunakan adalah penelitian meta analisis. Meta analisis adalah penelitian yang dilakukan peneliti dengan cara merangkum data penelitian, mereview dan menganalisis data dari beberapa hasil penelitian yang sudah ada sebelumnya Anugraheni, (2018). Pengumpulan data penelitian dilakukan melalui penelusuran google cendikia atau google scholar (https://scholar.google.co.id/) dan repository. Kata kunci yang digunakan dalam penelusuran adalah "media audio visual", "hasil belajar" dan "pembelajaran IPS".

Berdasarkan hasil penelusuran didapatkan beberapa artikel dari berbagai macam jurnal ilmiah online dan hasil skripsi di repository. Dari artikel dan hasil skripsi yang telah didapatkan, dipilih 9 artikel, 1 prosiding dan 2 hasil skripsi yang paling relevan. Artikel dan hasil skripsi yang dipilih harus memenuhi kriteria yaitu adanya pembahasan media audio visual, hasil belajar IPS atau yang relevan dengan pembelajaran IPS di sekolah dasar, dan adanya data sebelum tindakan dan sesudah tindakan dalam bentuk skor nilai. Teknik analisis data yang digunakan adalah dengan metode pembanding kuantitatif untuk mengetahui pengaruh penggunaan media audio visual. Analisis dilakukan dengan membandingkan selisih skor nilai sebelum tindakan pembelajaran menggunakan media audio visual dengan sesudah tindakan pembelajaran menggunakan media audio visual. Setelah itu, dibagi dengan skor sebelum tindakan pembelajaran menggunakan media audio visual (dalam bentuk \%) untuk mengetahui presentase peningkatan hasil belajar IPS siswa. 


\section{HASIL DAN PEMBAHASAN PENELITIAN}

Penelitian meta analisis ini mengikutsertakan hasil penelitian dari beberapa penelitian berikut ini:

1. Penggunaan Media Pembelajaran Audio Visual untuk Meningkatlan Hasil Belajar IPS pada Siswa Kelas IV SD oleh Arya Adittia pada tahun 2017.

2. Pengaruh Model Pembelajaran TPS (Think, Pair, Share) Berbantuan Media Audio Visual terhadap Hasil Belajar IPS Kelas V SD oleh Ni Made Dewi Sekarini, IB. Gede Surya Abadi dan Ni Nym. Ganing pada tahun 2014.

3. Penggunaan Media Audio Visual untuk Meningkatkan Prestasi Belajar pada Pembelajaran IPS Siswa Kelas V SDN Langung oleh Mulyadi, Febry Fahreza dan Rendi Julianda pada tahun 2018.

4. Media Audio Visual Berbasis Camtasia terhadap Hasil Belajar Tema Daerah Tempat Tinggalku Kelas IV SD oleh Budi Cahyaningtrias pada tahun 2017.

5. Penggunaan Media Audio Visual untuk Meningkatkan Hasil Belajar Pendidikan Kewarganegaraan Siswa Kelas IV SD Negeri 016 Bangkinang Kota oleh Rizki Ananda pada tahun 2017.

6. Penerapan Model Pembelajaran Kontekstual Berbantuan Media Audio Visual Kenampakan Alam (Asal Kelam) untuk Meningkatkan Hasil Belajar Siswa pada Materi Kenampakan Alam di Indonesia oleh Sofyan Mustoip, Dadang Kurnia, dan Prana Dwija Iswara pada tahun 2016.

7. Peningkatan Kualitas Pembelajaran IPS melalui Model Think Talk Write (TTW) Berbantuan Media Audio Visual oleh Rizqi Harisnawati dan Purnomo pada tahun 2015.

8. Model Pembelajaran Assure Bernuansa Lingkungan Berbantuan Media Audio Visual Berpengaruh terhadap Hasil Belajar IPS Siswa Kelas V SD Gugus Letkol Wisnu oleh Ni Wyn Pradnya Mitha, I Gd Meter dan I Ketut Ardana pada tahun 2014.

9. Penerapan Pembelajaran Inkuiri Berbantuan Media Audiovisual untuk Meningkatkan Aktivitas dan Hasil Belajar IPS Siswa Kelas V SD No. 3 Tibubeneng, Kuta Utara oleh Komang Ary Trisnadewi, I Wayan Darsana dan I Komang Ngurah Wiyasa pada tahun 2014.

10. Peningkatan Kualitas Pembelajaran IPS melalui Model Think Pair Share dengan Media Audio Visual pada Siswa Kelas VA SDN Wonosari 03 Semarang oleh Wahyu Pitaloka Dwi Lestari pada tahun 2014.

11. Pengaruh Model Pembelajaran Problem Based Instructio Berbantuan Media Audio Visual terhadap Hasil Belajar IPS Siswa Kelas V Gugus Srikandi Denpasar oleh Luh Dewi Puspitasari, Dr. I.G.A. Agung Sri Asri dan Drs. I Komang Ngurah Wiyasa pada tahun 2014.

12. Peningkatan Kualitas Pembelajaran IPS melalui Model Kooperatif Tipe STAD dengan Media Audio Visual pada Siswa Kelas IIIB SDN Karanganyar 02 oleh Nurul Apriliya pada tahun 2014.

Hasil penelitian dari 12 peneliti tersebut masih luas sehingga hasil penelitian harus diproses dengan cara dirangkum atau diambil intisarinya. Setelah itu, data dianalisis dengan metode pembanding kuantitatif. Hasil analisis pengaruh media audio visual dalam pembelajaran dapat dilihat pada Tabel 1 berikut ini:

Tabel. 1 Presentase Peningkatan Hasil Belajar IPS

\begin{tabular}{|llccccc|}
\hline \multirow{2}{*}{ No } & Topik & \multirow{2}{*}{ Peneliti } & \multicolumn{4}{c|}{ Peningkatan Hasil Belajar } \\
\cline { 4 - 7 } & Penelitian & Sebelum & Sesudah & Gain & Gain (\%) \\
\hline 1. & Media Audio & Arya & 65,45 & 80,82 & 15,37 & 23,37 \\
& $\begin{array}{l}\text { Visual, Hasil } \\
\text { Belajar IPS }\end{array}$ & Adittia & & & & \\
\hline
\end{tabular}



Dasar - Rosalia Isnaeni, Elvira Hoesein Radia

DOI : https://doi.org/10.31004/edukatif.v3i2.281

\begin{tabular}{|c|c|c|c|c|c|c|}
\hline 2. & $\begin{array}{l}\text { Model } \\
\text { Pembelajaran } \\
\text { TPS (Think } \\
\text { Pair Share), } \\
\text { Media Audio } \\
\text { Visual, Hasil } \\
\text { Belajar IPS }\end{array}$ & $\begin{array}{c}\text { Ni Made } \\
\text { Dewi } \\
\text { Sekarini, } \\
\text { IB. } \\
\text { Gede } \\
\text { Surya } \\
\text { Abadi, } \\
\text { Ni } \\
\text { Nym. } \\
\text { Ganing }\end{array}$ & 56,36 & 74,97 & 18,61 & 33,01 \\
\hline 3. & $\begin{array}{l}\text { Media Audio } \\
\text { Visual, } \\
\text { Prestasi } \\
\text { Belajar } \\
\text { Pembelajaran } \\
\text { IPS }\end{array}$ & $\begin{array}{l}\text { Mulyadi, } \\
\text { Febry } \\
\text { Fahreza, } \\
\text { Rendi } \\
\text { Julianda }\end{array}$ & 58,13 & 78,54 & 20,41 & 35,11 \\
\hline 4. & $\begin{array}{l}\text { Media Audio } \\
\text { Visual, } \\
\text { Camtasia, } \\
\text { Hasil Belajar } \\
\text { Tema Daerah } \\
\text { Tempat } \\
\text { Tinggalku }\end{array}$ & $\begin{array}{c}\text { Budi } \\
\text { Cahyani } \\
\text { ngtrias }\end{array}$ & 65 & 88,5 & 23,5 & 36,15 \\
\hline 5. & $\begin{array}{l}\text { Media Audio } \\
\text { Visual, Hasil } \\
\text { Belajar } \\
\text { Pendidikan } \\
\text { Kewarganegar } \\
\text { aan }\end{array}$ & $\begin{array}{c}\text { Rizki } \\
\text { Ananda }\end{array}$ & 44 & 80 & 36 & 81,81 \\
\hline 6. & $\begin{array}{l}\text { Model } \\
\text { Pembelajaran } \\
\text { Kontekstual, } \\
\text { Media Audio } \\
\text { Visual, Hasil } \\
\text { Belajar } \\
\text { Kenampakan } \\
\text { Alam } \\
\text { Indonesia } \\
\end{array}$ & $\begin{array}{c}\text { Sofyan } \\
\text { Mustoip, } \\
\text { Dadang } \\
\text { Kurnia, } \\
\text { Prana } \\
\text { Dwija } \\
\text { Iswara }\end{array}$ & 67,35 & 95,65 & 28,3 & 42,01 \\
\hline 7. & \begin{tabular}{lr}
\multicolumn{2}{l}{ Kualitas } \\
Pembelajaran \\
IPS, & Model \\
Think & Talk \\
Write & (TTW) \\
Media & Audio \\
Visual &
\end{tabular} & $\begin{array}{c}\text { Rizqi } \\
\text { Harisna } \\
\text { wati, } \\
\text { Purnom } \\
\text { o }\end{array}$ & 49,07 & 83,15 & 34,08 & 69,45 \\
\hline 8. & $\begin{array}{l}\text { Model } \\
\text { Pembelajaran } \\
\text { Assure, } \\
\text { Media Audio } \\
\text { Visual, Hasil } \\
\text { Belajar IPS }\end{array}$ & $\begin{array}{l}\text { Ni Wyn } \\
\text { Pradnya } \\
\text { Mitha, I } \\
\text { Gd } \\
\text { Meter, I } \\
\text { Ketut } \\
\text { Ardana } \\
\end{array}$ & 62,36 & 81,85 & 19,49 & 31,25 \\
\hline
\end{tabular}



Dasar - Rosalia Isnaeni, Elvira Hoesein Radia

DOI : https://doi.org/10.31004/edukatif.v3i2.281

\begin{tabular}{|c|c|c|c|c|c|c|}
\hline 9. & $\begin{array}{l}\text { Model Inkuiri, } \\
\text { Media Audio } \\
\text { Visual, } \\
\text { Aktivitas dan } \\
\text { Hasil Belajar } \\
\text { IPS }\end{array}$ & $\begin{array}{c}\text { Komang } \\
\text { Ary } \\
\text { Trisnade } \\
\text { wi, } \\
\text { I Wayan } \\
\text { Darsana, } \\
\text { I } \\
\text { Komang } \\
\text { Ngurah } \\
\text { Wiyasa }\end{array}$ & 63,76 & 84,33 & 20,57 & 32,26 \\
\hline 10 & $\begin{array}{l}\text { Kualitas } \\
\text { Pembelajaran } \\
\text { IPS, Model } \\
\text { Think Pair } \\
\text { Share, Media } \\
\text { Audio Visual }\end{array}$ & $\begin{array}{c}\text { Wahyu } \\
\text { Pitaloka } \\
\text { Dwi } \\
\text { Lestari }\end{array}$ & 55,2 & 88,9 & 33,7 & 61,05 \\
\hline 11 & $\begin{array}{l}\text { Model } \\
\text { Problem } \\
\text { Based } \\
\text { Instruction, } \\
\text { Media Audio } \\
\text { Visual, Hasil } \\
\text { Belajar IPS }\end{array}$ & $\begin{array}{c}\text { Luh } \\
\text { Dewi } \\
\text { Puspitas } \\
\text { ari, } \\
\text { Dr. } \\
\text { I.G.A. } \\
\text { Agung } \\
\text { Sri } \\
\text { Asri, } \\
\text { Drs. I } \\
\text { Komang } \\
\text { Ngurah } \\
\text { Wiyasa }\end{array}$ & 74,73 & 83,97 & 9,24 & 12,36 \\
\hline 12 & $\begin{array}{l}\text { Kualitas } \\
\text { Pembelajaran } \\
\text { IPS, Model } \\
\text { STAD, Media } \\
\text { Audio Visual }\end{array}$ & $\begin{array}{c}\text { Nurul } \\
\text { Apriliya }\end{array}$ & 59 & 73,26 & 14,26 & 24,16 \\
\hline & $\begin{array}{c}\text { rata Pengaruh M } \\
\text { Visual }\end{array}$ & a Audio & 60,03 & 82,82 & 22,79 & 37,96 \\
\hline
\end{tabular}

Berdasarkan hasil analisis pada Tabel 1 dapat dilihat bahwa media audio visual dapat meningkatkan hasil belajar IPS. Peningkatan hasil belajar IPS rata-rata sebesar 37,96 \% mulai dari peningkatan terendah $12,36 \%$ sampai yang tertinggi $81,81 \%$. Hasil belajar rata-rata sebelum menggunakan media audio visual dan sesudah menggunakan media audio visual mengalami peningkatan yang signifikan yaitu sebesar 37,96 \% Berikut ini adalah hasil Output Paired-Sample T Test:

Tabel 2. Statistik Sampel Berpasangan

\section{Paired Samples Statistics}

\begin{tabular}{llr|r|r|r} 
& & & \multicolumn{1}{c|}{$\begin{array}{c}\text { Std. } \\
\text { Deviation }\end{array}$} & \multicolumn{1}{c}{ Std. Error Mean } \\
\hline Pair1 & sebelum & 60,03 & 12 & 8,321 & 2,402 \\
\cline { 2 - 6 } & sesudah & 82,83 & 12 & 6,192 & 1,788 \\
\hline
\end{tabular}


310 Meta-Analisis Pengaruh Penggunaan Media Audio Visual Terhadap Hasil Belajar IPS Siswa di Sekolah Dasar - Rosalia Isnaeni, Elvira Hoesein Radia

DOI : https://doi.org/10.31004/edukatif.v3i2.281

Tabel 3. Korelasi Sampel Berpasangan

\section{Paired Samples Correlations}

\begin{tabular}{lr|r|rr} 
& N & Correlation & \multicolumn{2}{c}{ Sig. } \\
\hline Pair 1 sebelum \& sesudah & 12 &, 336 &, 285 \\
\hline
\end{tabular}

Tabel 4. Uji Sampel Berpasangan

\section{Paired Sample Test}

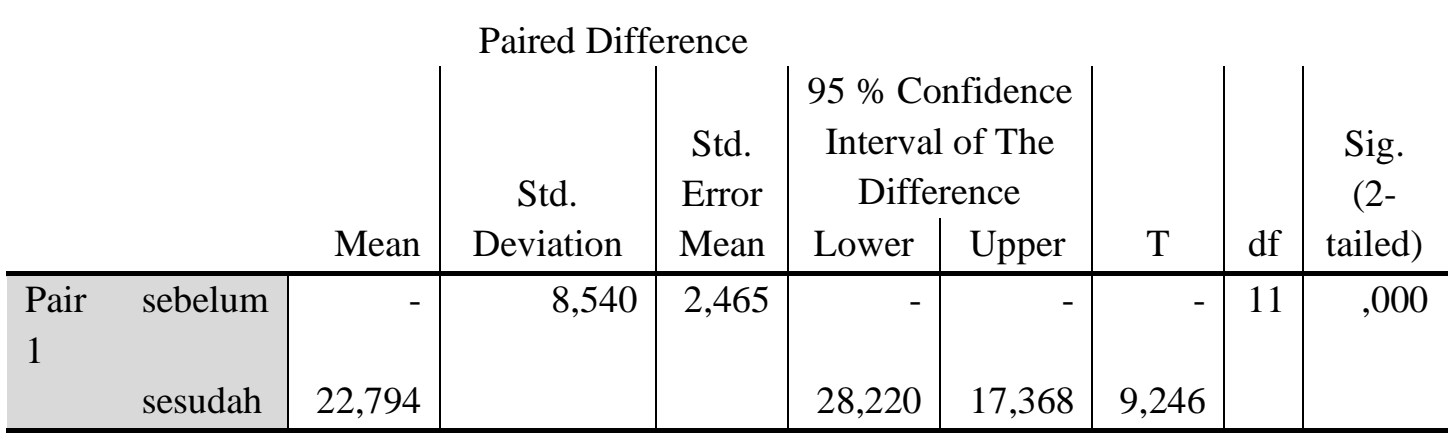

Tabel 5. Uji Effect Size

\begin{tabular}{cc}
\hline Batasan & Kategori \\
\hline $0,2-0,5$ & Kecil \\
\hline $0,5-0,8$ & Sedang \\
\hline$d>0,8$ & Besar \\
\hline
\end{tabular}

Besar pengaruh dari penggunaan media audio visual untuk meningkatkan hasil belajar IPS di Sekolah Dasar dapat diukur pengaruhnya dengan menggunakan uji Effect Size.

Effect size yang bertujuan untuk membuktikan pengaruh dari penggunaan media audio visual untuk meningkatkan hasil belajar IPS di Sekolah Dasar. Hasil penghitungan yang dilakukan oleh peneliti hasil yang tertera terdapat pada Tabel 2 yaitu skor sebelum (Pre-test) mempunyai Mean sebesar 60,03 dengan Standard Deviation sebesar 8,321. Kemudian pada saat dilakukan sesudah (Post-test) Mean mengalami kenaikan yaitu sebesar 82,83 dengan Standard Deviation yaitu 6,192. Rumus untuk menguji Effect Size berdasarkan Cohen:

$$
d=\frac{M_{\text {posttest }}-M_{\text {pretest }}}{\sqrt{\frac{\left(S D_{\text {pretest }}{ }^{2}+S D_{\text {posttest }}{ }^{2}\right)}{2}}}
$$

Keterangan:

$$
\begin{aligned}
& \mathrm{D} \quad=\quad \text { Effect Size } \\
& \mathrm{M}_{\text {pretest }} \quad=\quad \text { mean pretest } \\
& \mathrm{M}_{\text {posttest }}=\text { mean posttest } \\
& \mathrm{SD}_{\text {pretest }}=\text { Standar Deviasi pretest }
\end{aligned}
$$


311 Meta-Analisis Pengaruh Penggunaan Media Audio Visual Terhadap Hasil Belajar IPS Siswa di Sekolah Dasar - Rosalia Isnaeni, Elvira Hoesein Radia

DOI : https://doi.org/10.31004/edukatif.v3i2.281

$$
\mathrm{SD}_{\text {posttest }} \quad=\quad \text { Standar Deviasi posttest }
$$

Dari hasil hitungan yang dilakukan oleh peneliti menggunakan rumus uji Effect Size di atas, data yang tertera terdapat pada Tabel 2. Berikut ini adalah perhitungan menggunakan rumus Effect Size:

$$
\begin{aligned}
& d=\frac{M_{\text {posttest }}-M_{\text {pretest }}}{\sqrt{\frac{\left(S D_{\text {pretest }}{ }^{2}+S D_{\text {posttest }}{ }^{2}\right)}{2}}} \\
& d=\frac{82,83-60,03}{\sqrt{\frac{\left(8,321^{2}+6,192^{2}\right)}{2}}} \\
& d=\frac{22,8}{\sqrt{\frac{(69,239041+38,340864)}{2}}} \\
& d=\frac{22,8}{\sqrt{\frac{(107,579905)}{2}}} \\
& d=\frac{22,8}{\sqrt{53,7899525}} \\
& d=\frac{22,8}{7,3341633811} \\
& d=3,1087390361 \\
& d=3,10
\end{aligned}
$$

Berdasarkan hasil Output Paired-Sample T Test pada Tabel 2 menunjukkan bahwa media audio visual dapat meningkatkan hasil belajar IPS dengan nilai rata-rata 60,03 menjadi 82,82. Tabel 3 menunjukkan adanya relasi antara hasil belajar IPS rata-rata sebelum menggunakan media audio visual dengan sesudah menggunakan media audio visual sebesar 0,336. Menurut Sugiyono Yahdi \& Mutoharoh, (2016), interval koefisien antara 0,20 sampai 0,399 menunjukkan tingkat korelasi yang lemah.

Hasil uji hipotesis, $\mathrm{H}_{0}=$ tidak terdapat perbedaan yang signifikan hasil belajar IPS siswa sebelum pembelajaran menggunakan media audio visual dan $\mathrm{H}_{1}=$ terdapat perbedaan yang signifikan hasil belajar IPS siswa sebelum pembelajaran menggunakan media audio visual. Tabel 4 menunjukkan nilai Sig. (2-tailed) $(0,000)<\alpha(0,05)$ dan $\mathrm{t}_{\text {hitung }}=-9,246<\mathrm{t}_{\text {tabel }}=2,228$ sehingga $\mathrm{H}_{0}$ di tolak. Jadi, dapat disimpulkan bahwa terdapat perbedaan yang signifikan hasil belajar IPS siswa sebelum menggunakan media audio visual dan sesudah menggunakan media audio visual.

Menurut penghitungan Effect Ssize yang memperoleh hasil 3,10 dan dapat dilihat dari Tabel 5 menurut interprestasi uji effect size hasil dari 3,10 masuk kategori besar. Sehingga dapat disimpulkan bahwa dengan menggunakan media audio visual mempunyai pengaruh yang besar terhadap hasil belajar IPS sekolah dasar.

Berdasarkan hasil analisis penelitian dapat dilihat bahwa hasil belajar IPS siswa dari masing-masing penelitian dapat meningkatkan hasil belajar IPS dengan menggunakan media audio visual. Peningkatan hasil belajar pun berbeda-beda, ada yang peningkatannya besar dan ada juga peningkatannya yang cukup. Hal ini dapat dipengaruhi oleh beberapa hal, baik dari faktor internal maupun eksternal. Faktor internal berasal dari 
312 Meta-Analisis Pengaruh Penggunaan Media Audio Visual Terhadap Hasil Belajar IPS Siswa di Sekolah Dasar - Rosalia Isnaeni, Elvira Hoesein Radia

DOI : https://doi.org/10.31004/edukatif.v3i2.281

dalam diri siswa seperti kemampuan, bakat, minat dan kondisi kesehatan tubuh. Faktor eksternal berasal dari luar diri siswa seperti keluarga, sekolah dan lingkungan maasyarakat. Penelitian yang dilakukan dari daerah yang berbeda-beda juga berpengaruh terhadap hasil penelitian yang diperoleh. Tingkat kemampuan siswa di setiap daerah juga berbeda sehingga juga berpengaruh terhadap hasil belajar. Kondisi kesehatan siswa saat peneliti mengambil data juga berpengaruh, kondisi siswa yang kurang sehat membuat siswa mengerjakan tugas tidak maksimal dan bisa berdampak pada hasil belajar. Selain itu, pembelajaran menggunakan media audio visual dengan model pembelajaran yang berbeda juga memiliki kemungkinan peningkatan hasil belajar IPS berbeda-beda.

\section{KESIMPULAN}

Penggunaan media audio visual di sekolah dasar sudah banyak dilakukan oleh para peneliti. Hasil penelitian meta analisis menunjukkan bahwa media audio visual berpengaruh terhadap peningkatan hasil belajar IPS siswa sekolah dasar. Pengaruh penggunaan media audio visual adalah dapat meningkatkan hasil belajar IPS siswa kelas 5 sekolah dasar dengan peningkatan yang terendah 12,36 \% sampai yang tertinggi $81,81 \%$ dengan peningkatan rata-rata yang signifikan sebesar 37,96 \%. Saran bagi peneliti selanjutnya supaya lebih banyak menggunakan artikel maupun hasil skripsi yang diikutsertakan dalam penelitian meta analisis sehingga data yang diperoleh lebih banyak, lebih luas dan dapat dilihat lebih dalam hasil penelitiannya.

\section{UCAPAN TERIMA KASIH}

Penulis mengucapkan terimakasih kepada dosen pembimbing Elvira Hoesein Radia S.Pd., S.Mus., M.Pd. dan semua pihak yang telah membantu.

\section{DAFTAR PUSTAKA}

Adittia, A. (2017). PENGGUNAAN MEDIA PEMBELAJARAN AUDIO VISUAL UNTUK MENINGKATKAN HASIL BELAJAR IPS PADA SISWA KELAS IV SD. Mimbar Sekolah Dasar, 4(1), 9-20. https://doi.org/10.23819/mimbar-sd.v4i1.5227

Ananda, R. (2017). PENGGUNAAN MEDIA AUDIO VISUAL UNTUK MENINGKATKAN HASIL BELAJAR PENDIDIKAN KEWARGANEGARAAN SISWA KELAS IV SD NEGERI 016 BANGKINANG KOTA. Jurnal Basicedu, 1(1), 21-30.

Anhusadar, L. O. (2016). KREATIVITAS PENDIDIK DI LEMBAGA PAUD. Jurnal Al-Ta'dib, 9(1), 76-93.

Anugraheni, I. (2018). Meta Analisis Model Pembelajaran Problem Based Learning dalam Meningkatkan Keterampilan Berpikir Kritis di Sekolah Dasar. A Journal of Language, Literature, Culture, and Education POLYGLOT, 14(1), 9-18.

Apriliya, N. (2014). MELALUI MODEL KOOPERATIF TIPE STAD DENGAN MEDIA AUDIO VISUAL PADA SISWA KELAS IIIB SDN KARANGANYAR 02. Repository UNNES.

Cahyaningtrias, B. (2017). MEDIA AUDIO VISUAL BERBASIS CAMTASIA TERHADAP HASIL BEAJAR TEMA DAERAH TEMPAT penguasaan siswa terhadap materi pembelajaran . Kelebihan dari media audio visual ini , siswa. Prosiding Seminar Nasional PGSD 2017, 2572-2579.

Falahudin, I. (2014). Pemanfaatan Media dalam Pembelajaran. Jurnal Lingkar Widyaiswara, 1(4), 104-117.

Harisnawati, R., \& Purnomo. (2015). PENINGKATAN KUALITAS PEMBELAJARAN IPS MELALUI MODEL THINK TALK WRITE (TTW) BERBANTUAN MEDIA AUDIO VISUAL. Joyful Learning Journal, 4(5), 57-65.

Hutauruk, P., \& Simbolon, R. (2018). MENINGKATKAN HASIL BELAJAR SISWA DENGAN ALAT 
313 Meta-Analisis Pengaruh Penggunaan Media Audio Visual Terhadap Hasil Belajar IPS Siswa di Sekolah Dasar - Rosalia Isnaeni, Elvira Hoesein Radia

DOI : https://doi.org/10.31004/edukatif.v3i2.281

PERAGA PADA MATA PELAJARAN IPA KELAS IV SDN NOMOR 14 SIMBOLON PURBA. SEJ (School Education Journal), 8(2).

Ibda, F. (2015). PERKEMBANGAN KOGNITIF : TEORI JEAN PIAGET. Jurnal Intelektualita, 3, 27-38.

Lestari, W. P. D. (2014). PENINGKATAN KUALITAS PEMBELAJARAN IPS MELALUI MODEL THINK PAIR SHARE DENGAN MEDIA AUDIO VISUAL PADA SISWA KELAS VA SDN WONOSARI 03 SEMARANG. Repository UNNES.

Mitha, N. W. P., Meter, I. G., \& Ardana, I. K. (2014). MODEL PEMBELAJARAN ASSURE BERNUANSA LINGKUNGAN BERBANTUAN MEDIA AUDIOVISUAL BERPENGARUH TERHADAP HASIL BELAJAR IPS SISWA KELAS V SD GUGUS LETKOL WISNU. Jurnal Mimbar PGSD Universitas Pendidikan Ganesha, 2.

Mulyadi, Fahreza, F., \& Julianda, R. (2018). PENGGUNAAN MEDIA AUDIO VISUAL UNTUK MENINGKATKAN PRESTASI BELAJAR PADA PEMBELAJARAN IPS SISWA KELAS V SDN LANGUNG. Jurnal Visipena, 9(1), 131-146.

Mustoip, S., Kurnia, D., \& Iswara, P. D. (2016). PENERAPAN MODEL PEMBELAJARAN KONTEKSTUAL BERBANTUAN MEDIA AUDIO VISUAL KENAMPAKAN ALAM ( ASAL KELAM ) UNTUK MENINGKATKAN HASIL BELAJAR SISWA PADA MATERI KENAMPAKAN ALAM DI INDONESIA. Jurnal Pena Ilmiah, 1(1), 561-570.

Puspiatasari, L. D., Asri, I. G. A. A. S., \& Komang, I. W. N. (2014). PENGARUH MODEL PEMBELAJARAN PROBLEM BASED INSTRUCTION BERBANTUAN MEDIA AUDIO VISUAL TERHADAP HASIL BELAJAR IPS SISWA KELAS V GUGUS SRIKANDI DENPASAR. Jurnal Mimbar PGSD Universitas Pendidikan Ganesha, 2(1).

Rinanto, A. (1982). Peranan Media Audio Visual Dalam Pendidikan. Yogyakarta: Yayasan Kanisius (Anggota IKAPI).

Sekarini, N. M. D., Abadi, I. G. S., \& Ganing, N. N. (2014). PENGARUH MODEL PEMBELAJARAN TPS ( THINK , PAIR , SHARE ) BERBANTUAN MEDIA AUDIO VISUAL TERHADAP HASIL BELAJAR IPS KELAS V SD. Jurnal Mimbar PGSD Universitas Pendidikan Ganesha, 2.

Shafa. (2014). KARAKTERISTIK PROSES PEMBELAJARAN KURIKULUM 2013. Jurnal Dinamika Ilmu, 14(32), 81-96.

Sista, T. R. (2017). Implementasi Manajemen Kurikulum Dalam Meningkatkan Mutu Pendidikan. Jurnal Educan, 1(1), 25-45.

Trisnadewi, A. K., Darsana, I. W., \& Wiyasa, I. K. N. (2014). PENERAPAN PEMBELAJARAN INKUIRI BERBANTUAN MEDIA AUDIOVISUAL UNTUK MENINGKATKAN AKTIVITAS DAN HASIL BELAJAR IPS SISWA KELAS V SD NO. 3 TIBUBENENG, KUTA UTARA. E-Jurnal Mimbar PGSD Universitas Pendidikan Ganesha, 2(1).

Yuzarion. (2017). Faktor yang mempengaruhi prestasi belajar peserta didik. Jurnal Ilmu Pendidikan, 2(1), 107-117. 